\title{
実船における軸系横振動と船体振動の関係 および軸系横振動の計算結果についで
}

\author{
吉田 真 $^{* *}$. 仁科邦 - ${ }^{* *}$
}

\section{1. まえがき}

大形タービン船において, 船体に伝達される振動は, 主として推進軸系によりじゃっ起されるが，中でも軸系 横振動が船体振動におよぼす影響を究明するため，本稿 では軸系横振動と船体振動について実船計測を実施し, 更に, 軸受配置, 軸径の選定および軸受台の強度などが, 軸系横振動の危険回転数におよぼす影響を調べるため， 軸系横振動の計算法について, 三通りの計算法を試み, それらの妥当性に関して検討した。

まず，実船計測については，15万トンから 25 万トンまでの 3 隻の船に対し, 軸系横振動, 機関 室二重底および上甲板, 船橋など多数の点を計測 した。ただし，これまで得られた計測值では，軸 系横振動の共振現象を起こした例が少ないため, その真ぴょう性を確認する機会がなかった. しか るに，筆者らが行なった計測船のうち一隻のみに， 共振現象が測定されたので, その振動を確認した 上，以下に述べる軸系モデルに基づいて，振動計 算を行ない，他の計算法との対比ならびに実船計 測值との比較を行なった.

筆者らの計算においては, 軸の回転数とふれま わりの速度が異なる場合のジャイロモーメントの影響を 考慮しており，計算の目的から考えて当然のことである が，ふれ回りの速度は軸回転のプロペラ枚数倍とした。

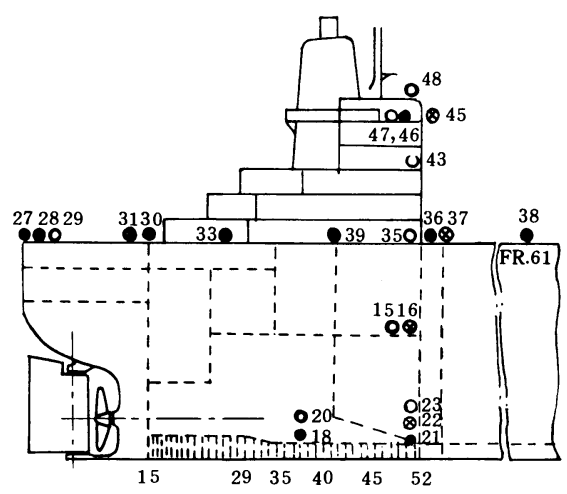

図 2.1 B 船

* 原稿受付 昭和 50 年 4 月 10 日

舶用機関国際シンポジゥム一般講演 (昭和 48 年 11 月 14 日)

**石川島播磨重工業 (株) 点造船所 (吳市昭和通り 2 丁目)
なお，軸受台を支持する弾性要素のバネ常数と共に軸受 油膜の弾性および減衰係数, さらに軸受部の質量の影響 をも考慮した。

\section{2. 軸系の振動および船体振動の計測}

2.1 計測船と計測䓢所表 2.1 に示す A，B よびC船について，満載およびバラスト状態における振 動計測を行なった。また, 計測は図 2.1 から図 2.3 に示 す計測点で実施した。

2.2 計測万法 軸系横振動の計測法については,

表 2.1

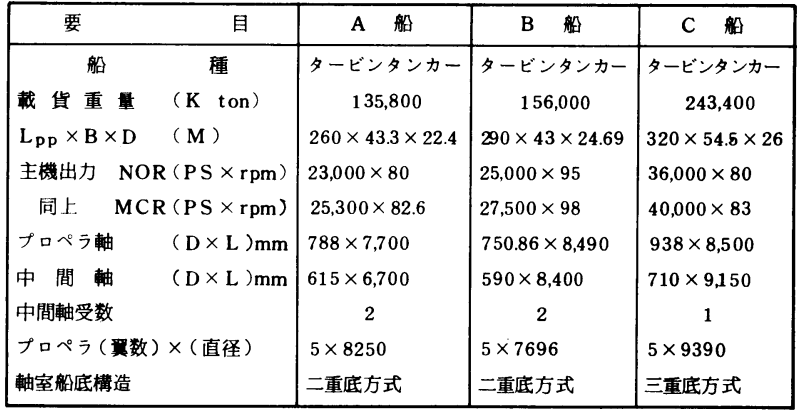

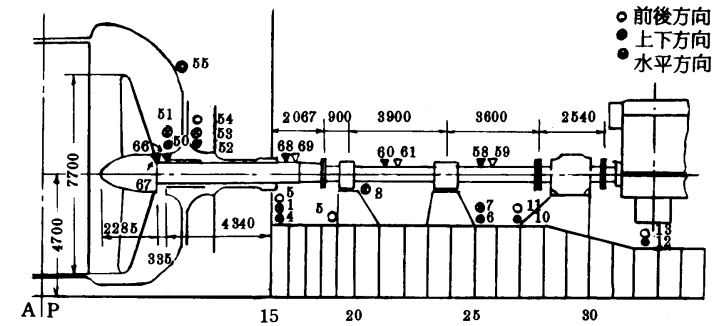

図 2.2 B船

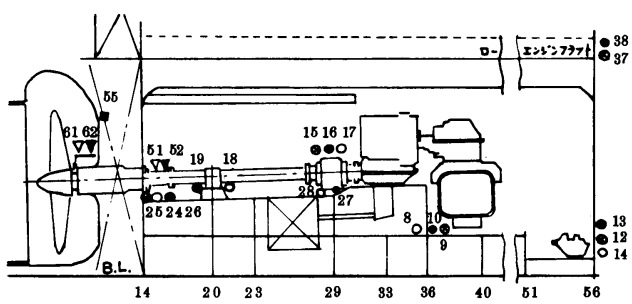

因 2.3 C 船 


\begin{tabular}{|c|c|c|c|c|}
\hline 計 測物 & 計測器具 & & & \\
\hline 系 & カンチレバー & \multirow{2}{*}{$\begin{array}{l}\text { 動的ひず } \\
\text { み計 }\end{array}$} & \multirow{2}{*}{$\mid \begin{array}{l}\text { ローパス } \\
\text { フィルタ }\end{array}$} & \multirow{2}{*}{$\begin{array}{l}\text { オンロ } \\
\text { グラフ }\end{array}$} \\
\hline 船 尾 管 & 加速度計 & & & \\
\hline スラスト軸受 & 速度計 & & & コンピュ \\
\hline 中 間 軸 受 & 同上 & & & 器付オシ \\
\hline 機関室二重底 & 同上 & & & ログラフ \\
\hline 船 & 同上 & & & $-1500)$ \\
\hline 回転 $\checkmark-ク$ & & & & \\
\hline
\end{tabular}

図 2.4
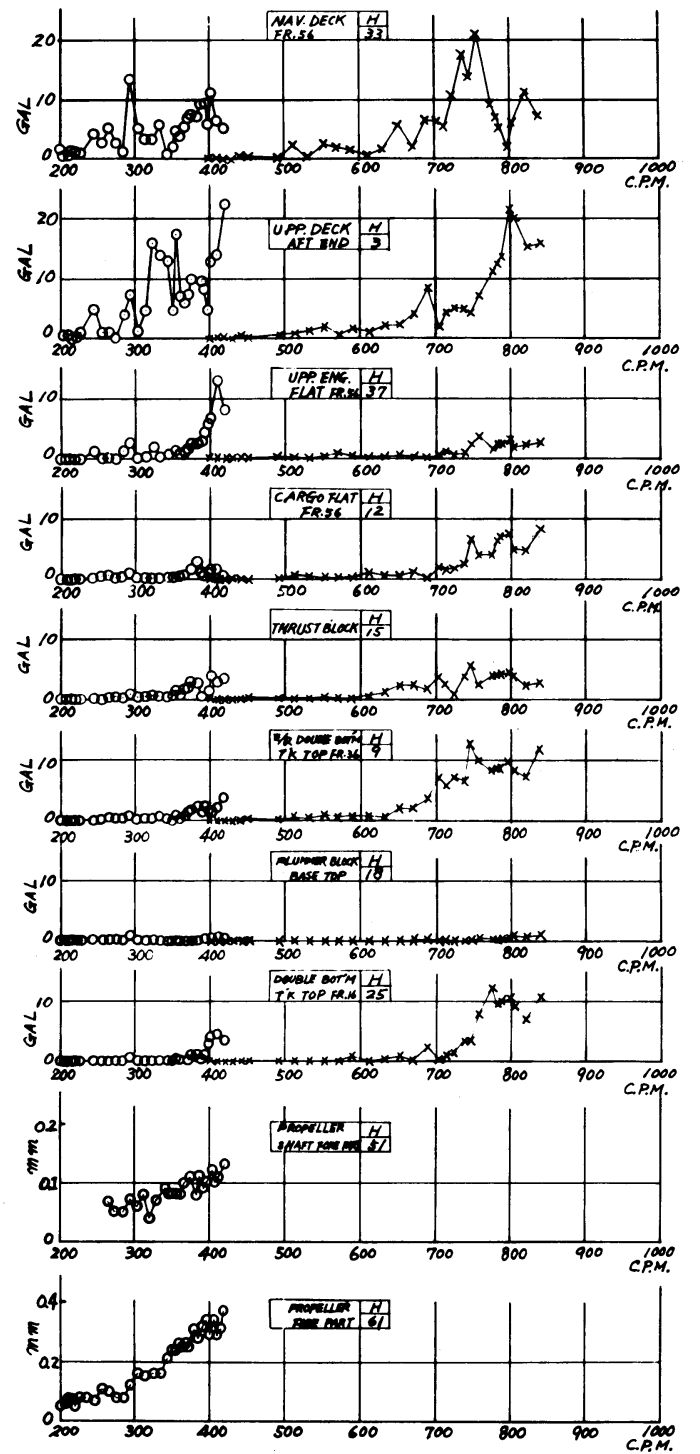

図 2.8 C 船水平方向振動レゾナンスカーブ

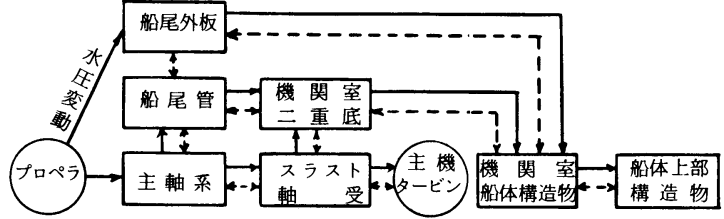

図 2.5 主軸系一船体振動フローチャート

既刊の本学会誌記載 ${ }^{1)}$ と同様な方法で計測した。軸以外 の振動は加速度計，または，速度形振動計によって計測 した.その主要部の計測システムを図 2.4 に示す.

B 船およびC 船については, 速度形振動計で検出した 信号をコンピュータを用いてデータ処理を行ない，共振 曲線, 振動次数扰よび位相角を自動的に記録する装置 ${ }^{2)}$ を利用した。

2.3 測定結果の説明軸系横振動と船体振動は 図 2.5 に示すフローチャートのように, 推進器, 軸系, 船尾管, 機関室二重底および船体構造物とが，相互にか つ複雑に影響しあっていると考えられる，多くの測定結 果のうち主要部につき, 図 $2.6 よ り$ 図 2.9 に示した。積 載条件は満載またはバラスト状態のいずれかである。 A 船の詳細は本学会誌 ${ }^{1)}$ にけい載のため省略する.

2.3.1 軸系横振動と船体振動の関係

（1） 3 隻の船とも，プロペラ翼数が 5 翼であるため, 軸系横振動の振動次数は, 5 次と 10 次成分であり, 10 次 成分の方は各船とも小さかった。なお，カンチレバー方 式による計測結果は, 機関室二重底との相対振動を表わ している訳で，この点を留意しておく必要がある.

各船の振動については, 表 2.2 にそれぞれの数值を示 した. 図 2.6 , 図 2.7 , 図 2.8 および図 2.9 が示すよう に，各船とも主軸の回転数の上昇につれて，軸系横振動 の振幅が増大する傾向がある． A 船， C 船では，明瞭な 振動のピークはみられず，プロペラ強制力による強制振 動によって振幅が主機回転数上昇と共に増加している。

B 船では，軸系横振動に振動のピークが確認された. ここで明確にしておきたい点は, 中間軸, プロペラ軸首 部およびプロペラ首部にそれぞれ，表 2.2 に示す振動の ピークがあるが, プロペラ軸首部に例をあげると, カン 

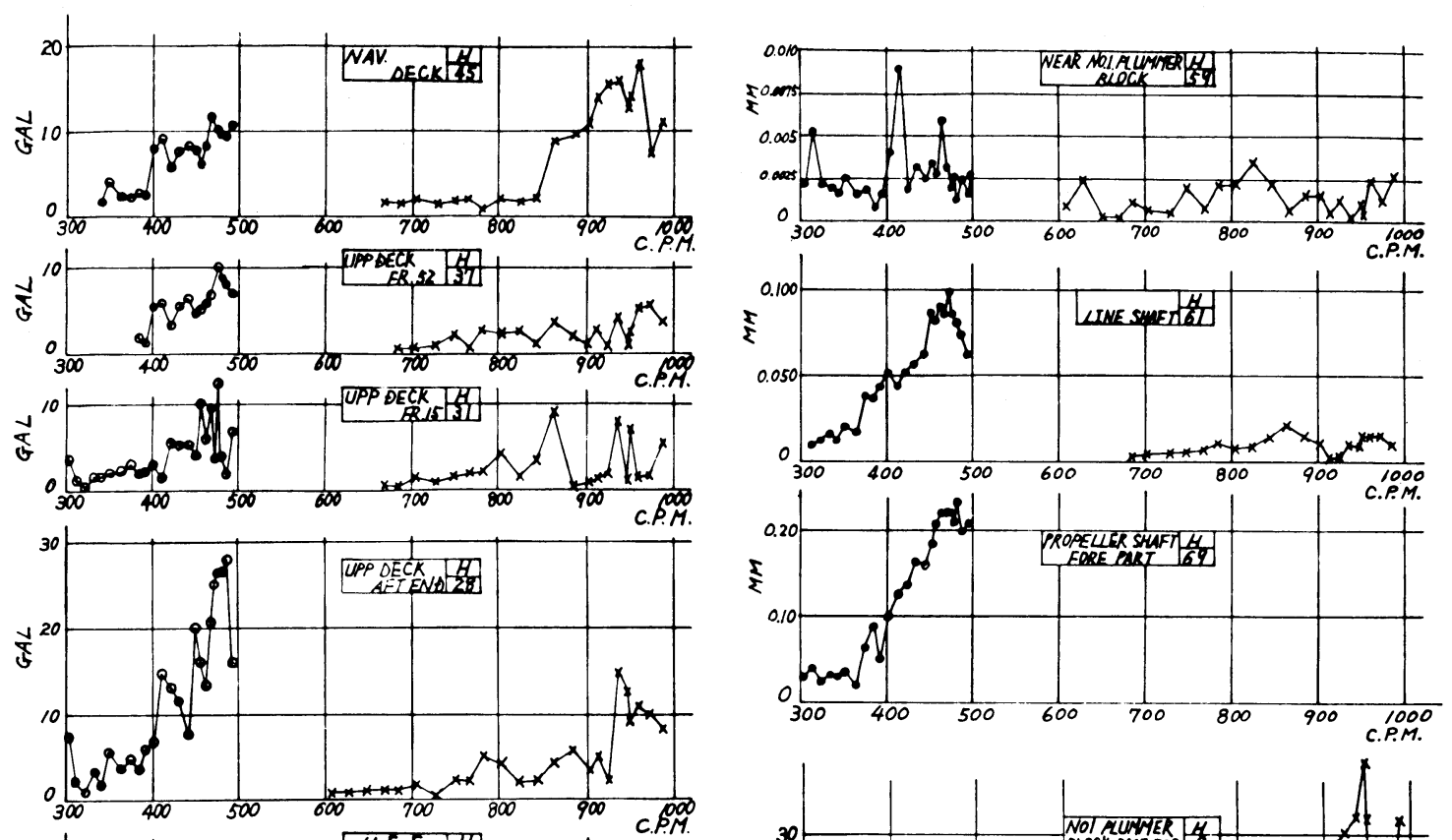

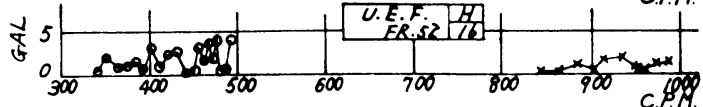
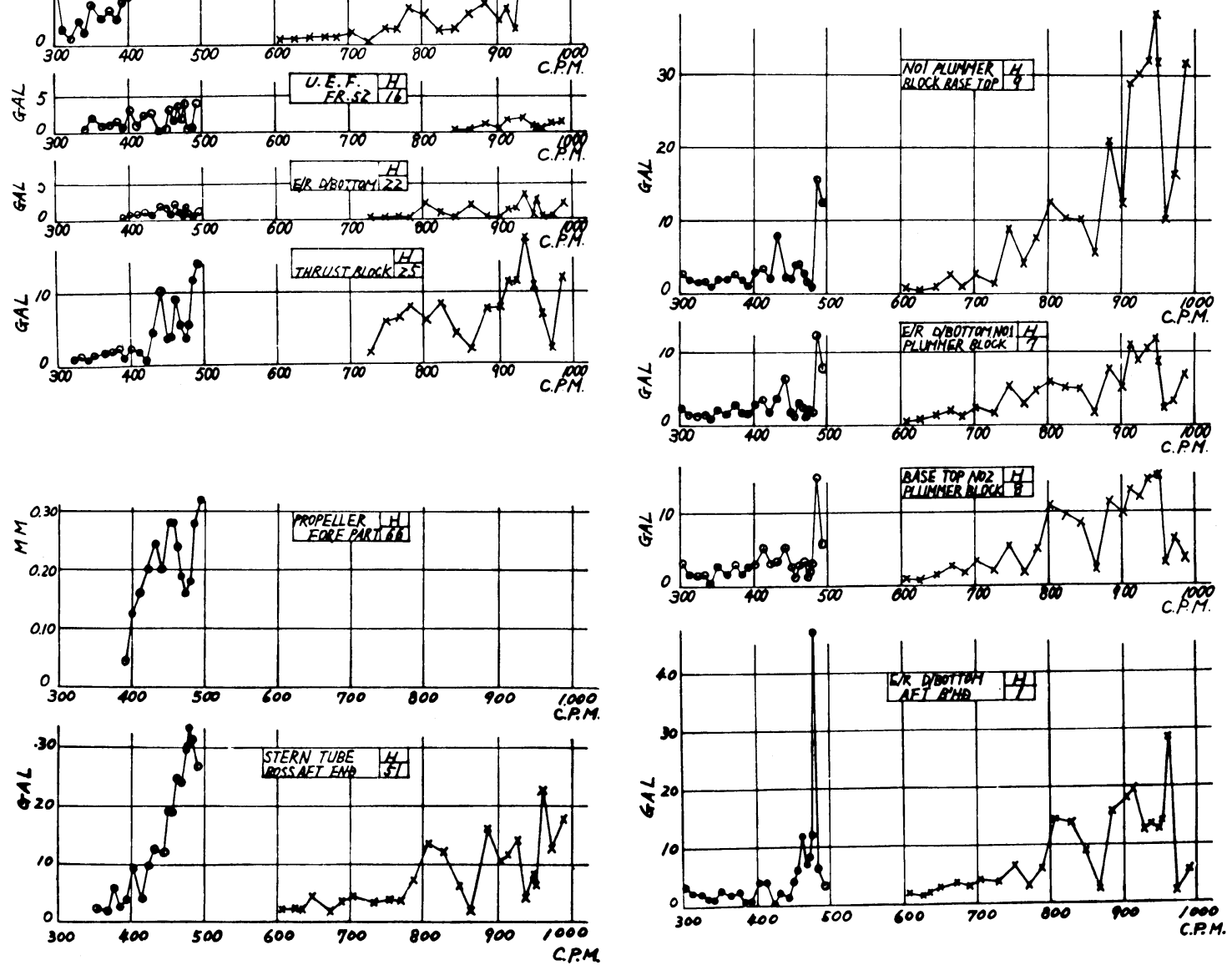

図 2.6 B 船水平方向振動レゾナンスカーブ 

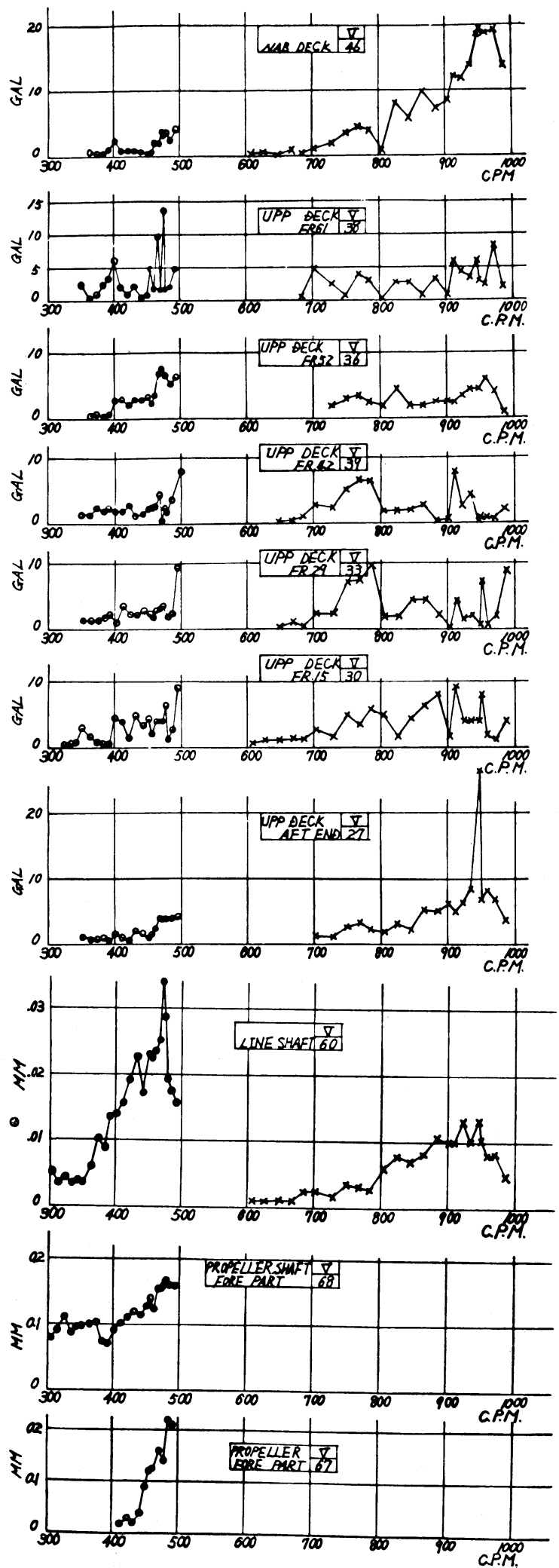

日本舶用機関学会誌 第 10 巻 第 9 号
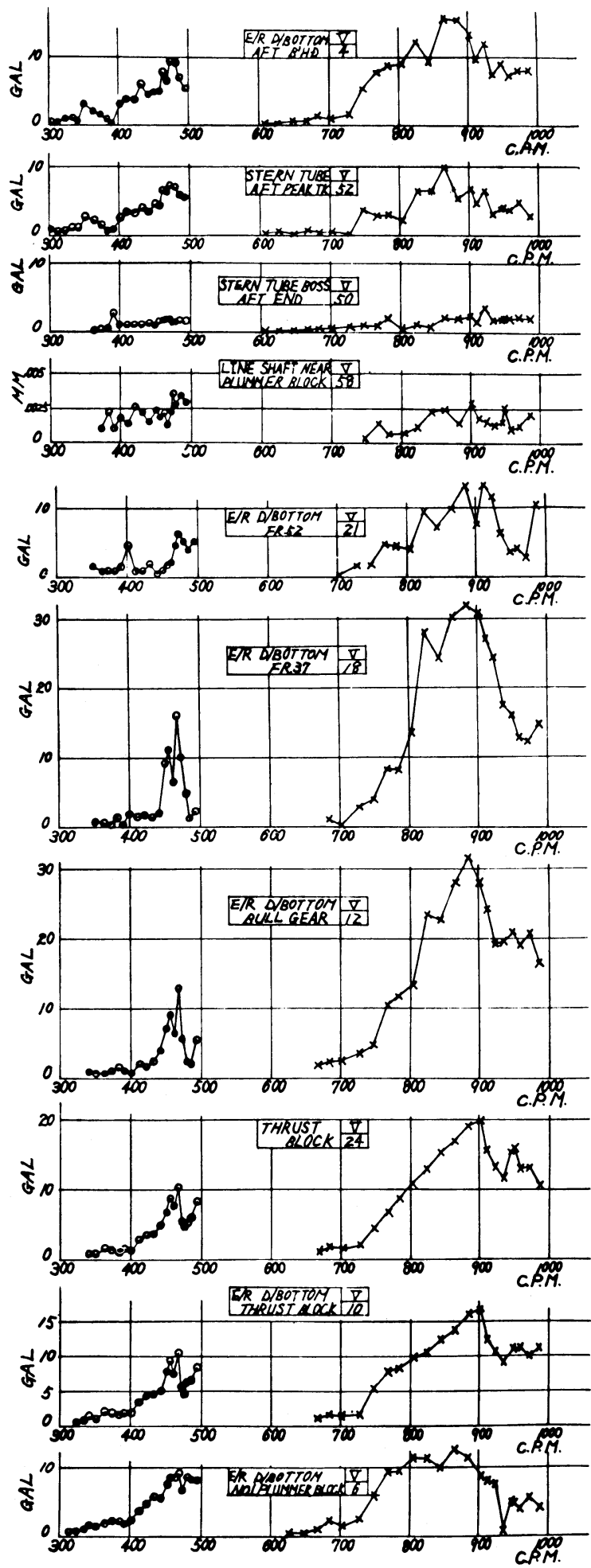

図 2.7 B 船上下方向振動レゾナンスカーブ 

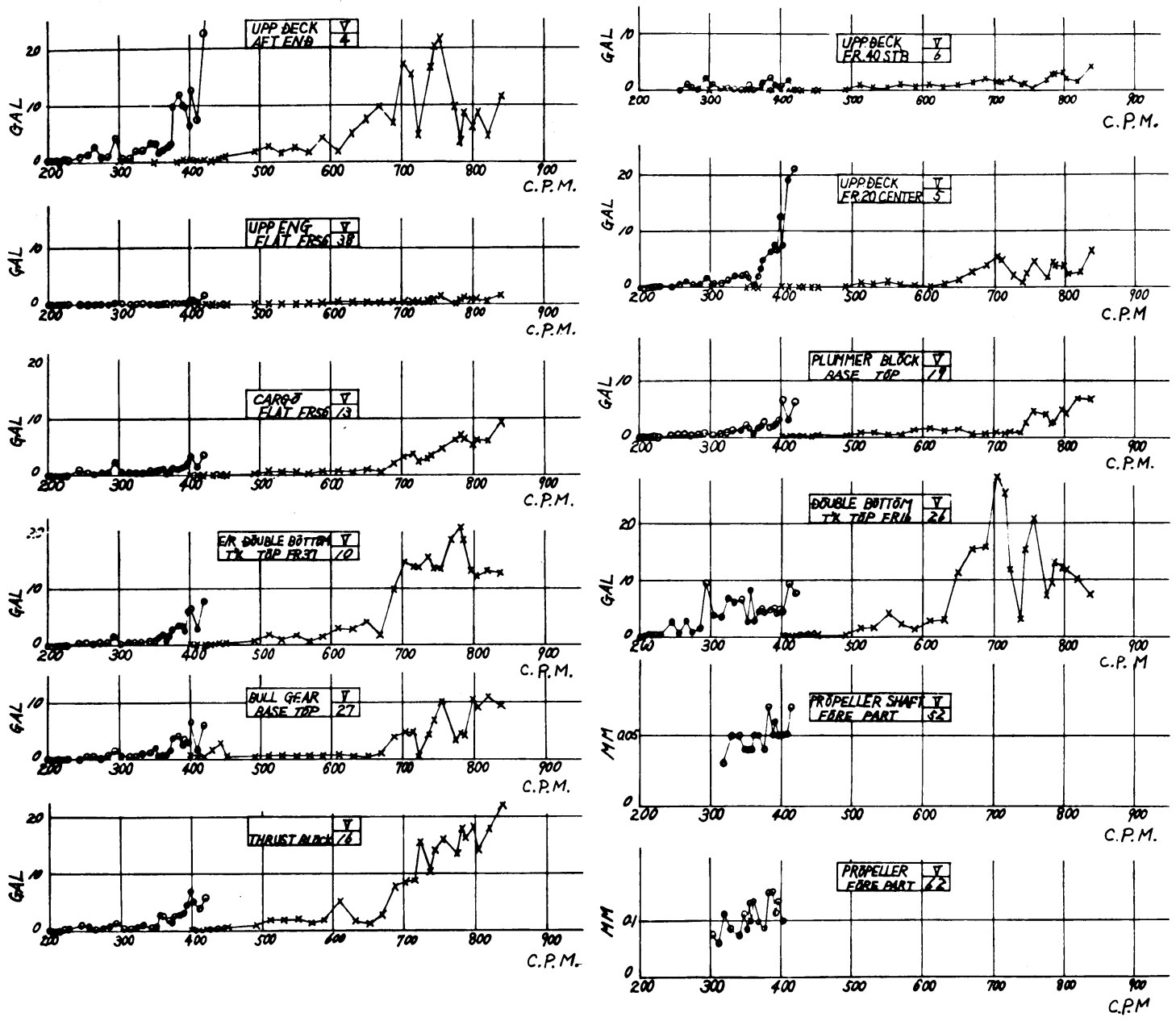

図 2.9 C 船上下方向振動レゾナンスカーブ

表 2.2 軸系横振動計測値

単振幅. 単位: mm

\begin{tabular}{|c|c|c|c|c|c|c|c|}
\hline & & A 船 & \multicolumn{3}{|c|}{ B 船 } & \multicolumn{2}{|c|}{ C 船 } \\
\hline & 振動方向 & プロペラ軸首部 & 中 間 軸 & プロペラ軸首部 & プロペラ首 部 & プロペラ軸首部 & プロペラ首 部 \\
\hline $\begin{array}{l}\text { 满 } \\
\text { 載 }\end{array}$ & 平 & $\begin{array}{c}80.8 \mathrm{rpm} \\
\max \\
0.11\end{array}$ & - & $\begin{array}{c}98.0 \mathrm{rpm} \\
\max \\
0.23\end{array}$ & - & $\begin{array}{c}84.0 \mathrm{rpm} \\
\max \\
0.12\end{array}$ & $\begin{array}{c}84.0 \mathrm{rpm} \\
\max \\
0.37\end{array}$ \\
\hline $\begin{array}{l}\text { 状 } \\
\text { 態 }\end{array}$ & 下 & $\begin{array}{c}82.6 \mathrm{rpm} \\
\max \\
0.07\end{array}$ & - & $\begin{array}{c}475 \mathrm{cpm} \\
0.16\end{array}$ & - & $\begin{array}{c}82.5 \mathrm{rpm} \\
\max \\
0.07\end{array}$ & $\begin{array}{c}77 \mathrm{rpm} \\
\max \\
0.15\end{array}$ \\
\hline $\begin{array}{l}\text { i } \\
\bar{j} \\
\text { ス }\end{array}$ & 水 & $\begin{array}{c}82.5 \mathrm{rpm} \\
\max \\
0.07\end{array}$ & $\begin{array}{l}472 \mathrm{cpm} \\
0.10\end{array}$ & $\begin{array}{c}475 \mathrm{cpm} \\
0.223\end{array}$ & $\begin{array}{c}454 \mathrm{cpm} \\
0.28\end{array}$ & $\begin{array}{l}79.6 \mathrm{rpm} \\
\max \\
0.13\end{array}$ & $\begin{array}{l}80 \mathrm{rpm} \\
\max \\
0.34\end{array}$ \\
\hline $\begin{array}{l}\text { ト } \\
\text { 状 } \\
\text { 態 }\end{array}$ & 上 下 & $\begin{array}{c}82.0 \mathrm{rpm} \\
\max \\
0.044\end{array}$ & $\begin{array}{c}470 \mathrm{cpm} \\
0.034\end{array}$ & $\begin{array}{c}480 \mathrm{cpm} \\
0.17\end{array}$ & $\begin{array}{c}482 \mathrm{cpm} \\
0.225\end{array}$ & $\begin{array}{c}81.5 \mathrm{rpm} \\
\max \\
0.09\end{array}$ & $\begin{array}{c}83 \mathrm{rpm} \\
\max \\
0.09\end{array}$ \\
\hline
\end{tabular}


表 2.3 B 船バラスト状態振動

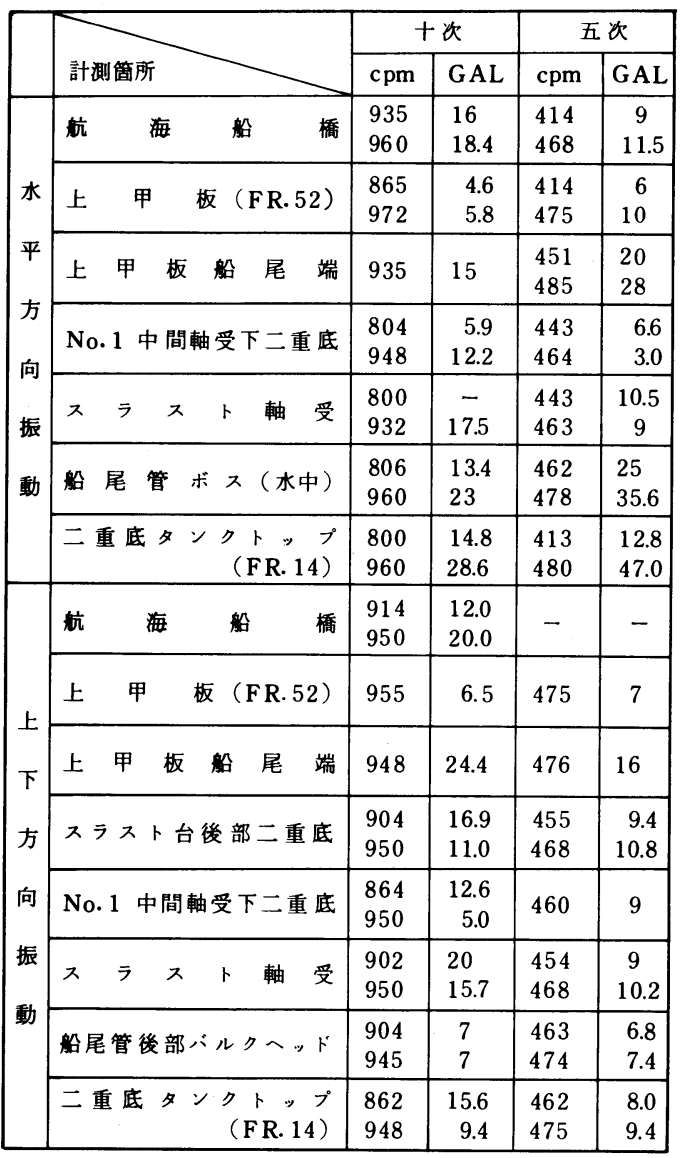

チレバー方式で計測しているため，二重底の振動を相対 的に拾ったのではないかとの疑問がわくが，表 2.3 を対 比してみると，プロペラ軸首部に近い機関室二重底の振 動はその大きさが異なること，およびピーク点の振動数 もずれているなどから，この值はプロペラ軸固有のもの と考えてよい.この点はプロペラ首部についても同様に 考えられる.

つぎに，各船の軸系横振動と船体振動の相関について 述べる. A 船は B 船および C 船と類似の部分が多いので 説明を省略し， B 船のバラスト状態から説明する。

プロペラ軸と軸受を含む振動系の共振点であると考え られる $475 \mathrm{cpm}$ の振動数をもつ振動は, 船尾管, 上甲 板，船橋甲板などにも明りように現われており，機関室 二重底と共振振動系を構成していると思われる。また， プロペラ首部の水平方向振動の共振点と考えられる 454 $\mathrm{cpm}$ の振動も, スラスト軸受, 機関室二重底, 上甲板お よび航海船橋にその振動数の付近のピークが表われてい る.

一方, 満載状態では, 主軸回転数の上昇と共に，振幅 が漸増しており，92 r pmおよび $96.7 \mathrm{rpm}$ 付近に振動の

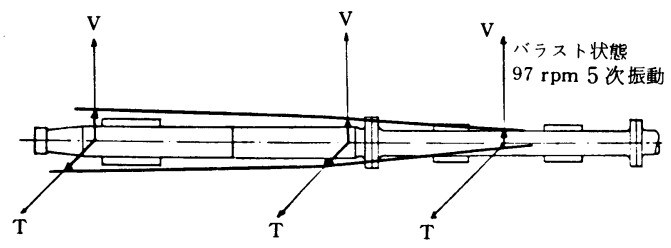

図 2.10 軸系横振動のモードカーブ

ピークが存在するようにみえるが，共振点であるかどう かは確認出来なかった。

C 船の場合は, 明りような共振点は見いだされなかっ た. 両船とも軸系横振動の水平方向振幅は, 上下方向振 幅の約 1.5〜2.0 倍の值となっている.

（2）軸系横振動の振動モードを図 2.10 に示す.計測結 果からは振動の，節がはっきりしないが，次節で述べる計 算結果では節が存在しており, 計測点の不足もその一因 と考えられる.

2.3.2 船体振動 プロペラ起振力による船体振動 の状況をは握するため, 振動のモードをB船に対して求 め, その結果を図 2.11 および図 2.12 に示す.

水平方向 5 次振動について説明すると，機関室二重底 では, 船尾にゆくにつれて振幅が増大しており，上甲板
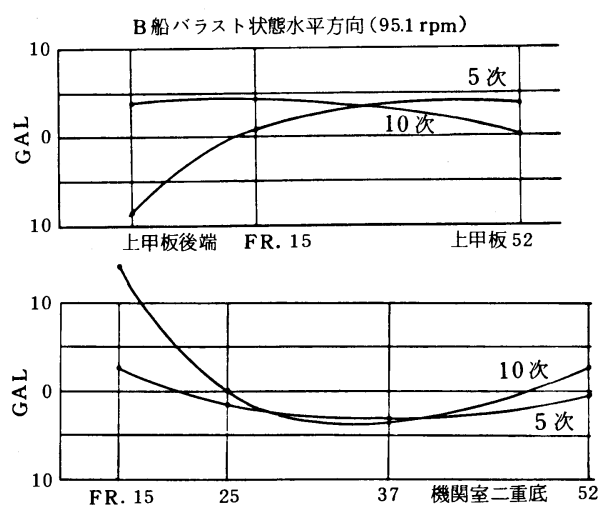

図 2.11 船体振動モードカーブ
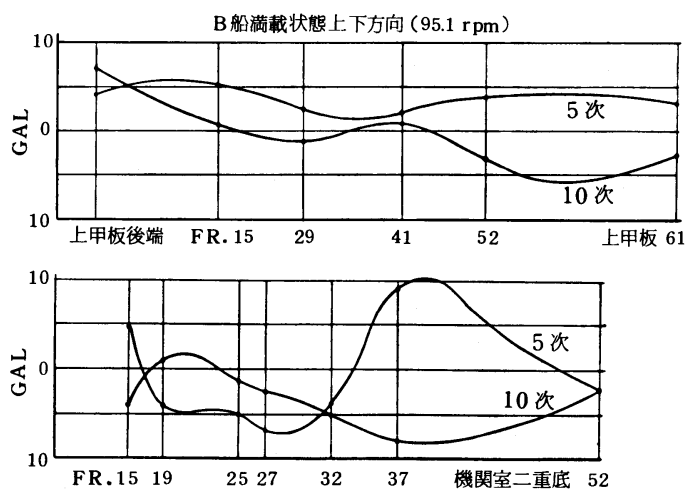

図 2.12 船体振動モードカーブ 
表 2.4 C 船バラスト状態船体振動

\begin{tabular}{|c|c|c|c|c|c|}
\hline & \multirow{2}{*}{ 計測箇所 } & \multicolumn{2}{|c|}{10 次 } & \multicolumn{2}{|c|}{5 次 } \\
\hline & & \multicolumn{2}{|c|}{\begin{tabular}{l|l}
$\mathrm{cnm}$ & $\mathrm{GAI}$ \\
\end{tabular}} & \multirow{2}{*}{$\begin{array}{l}\text { cpm } \\
284 \\
385\end{array}$} & \multirow{2}{*}{$\begin{array}{c}\text { GAL } \\
20 \\
14\end{array}$} \\
\hline \multirow{3}{*}{ 平 } & 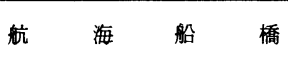 & $\begin{array}{l}720 \\
815\end{array}$ & $\begin{array}{l}20.8 \\
11.5\end{array}$ & & \\
\hline & 上甲 板 船 尾 管 & 720 & 14 & 384 & 17 \\
\hline & 一重底タンク & 782 & 18.5 & & \\
\hline 方 & (FR. 36) & 805 & 13.5 & - & - \\
\hline \multirow{3}{*}{$\begin{array}{l}\text { 向 } \\
\text { 振 } \\
\text { 動 }\end{array}$} & スラスト軸 受 & 780 & 9.0 & 380 & 4 \\
\hline & 中 間 軸 受 台 & & & 微 小 & 徽 小 \\
\hline & $\begin{array}{r}\text { 二重底タンクトップ } \\
(\mathrm{FR} \cdot 14)\end{array}$ & $\begin{array}{l}735 \\
782\end{array}$ & $\begin{array}{l}9.0 \\
8.0\end{array}$ & & 徽 小 \\
\hline \multirow{2}{*}{$\begin{array}{l}\text { 上 } \\
\text { 下 }\end{array}$} & 上甲 板 船 尾 端 & $\begin{array}{l}725 \\
752 \\
802\end{array}$ & $\begin{array}{r}9 \\
12 \\
30\end{array}$ & 385 & 20 \\
\hline & $\begin{array}{r}\text { 二重底タンクトゥプ } \\
(\text { FR. 36) }\end{array}$ & $\begin{array}{l}725 \\
780 \\
805\end{array}$ & $\begin{array}{l}32 \\
47 \\
21\end{array}$ & 408 & 16 \\
\hline 向 & スラスト軸 受 & $\begin{array}{l}725 \\
780 \\
805\end{array}$ & $\begin{array}{l}32 \\
47 \\
21\end{array}$ & 408 & 16 \\
\hline \multirow{2}{*}{$\begin{array}{l}\text { 振 } \\
\text { 動 }\end{array}$} & 中 間 軸 受 台 & $\begin{array}{l}782 \\
802\end{array}$ & $\begin{array}{r}8 \\
13\end{array}$ & 408 & 10 \\
\hline & $\begin{array}{r}\text { 二重底タンクトップ } \\
(\text { FR.14） }\end{array}$ & $\begin{array}{l}720 \\
782 \\
805\end{array}$ & $\begin{array}{l}11 \\
22 \\
15.5\end{array}$ & 408 & 10 \\
\hline
\end{tabular}

のモードと比較すると, 逆位相のねじり振動をしている ことがわかった. 一方, 10 次振動の方は上記のような逆 位相現象は表われなかった。

つぎに， B 船およびC 船のバラスト状態における船体 各部の振動について, その相関性を求めるため, 共振点 と考えられるものおよび特記事項につき表 2.3 および表 2.4 を作成した.これらの表の計測值は, 軸系横振動に よってじゃっ起される 5 次の振動 (10 次振動は比較的小 さい)と,つぎに述べる水圧変動の 5 次および 10 次振動, そのほかかじに伝達されるプロペラ水力による振動など が，合成されて船体振動として計測されたものを表わし ている.

船体前後振動の起振源としての軸系縦振動についても, 各船とも計測を行ない, スラスト軸受と航海船橋そのほ かと共振している場合のあることがわかった。

水圧変動と船体振動の関係について調査するため, B 船のバラスト状態および満載状態に関して計測を行ない, その計測結果を表 2.5 にまとめた. 一般的傾向として, 5 次の成分が 10 次の成分より大きく，主軸の回転の上昇 につれて振幅が増大していることが確認された.ただし， 本稿では，水圧変動と船体振動の相関関係につき検討す る所まで出来なかった。

2.3.3 軸系横振動の加振実験 C 船に関しては, 海上試運転時軸系横振動の共振点が表われなかったので,
表 2.5 船尾部水圧変動

単位: $\mathrm{kg} / \mathrm{cm}^{2}$

\begin{tabular}{|c|c|c|c|c|}
\hline & B & 船 & $\mathrm{C}$ & 船 \\
\hline 状態 次数 & 5 次 & 10 次 & 5 次 & 10 次 \\
\hline パラスト & 0.03 & 0.013 & 0.11 & 0.03 \\
\hline 満 載 & 0.012 & 0.012 & 0.07 & 0.013 \\
\hline
\end{tabular}
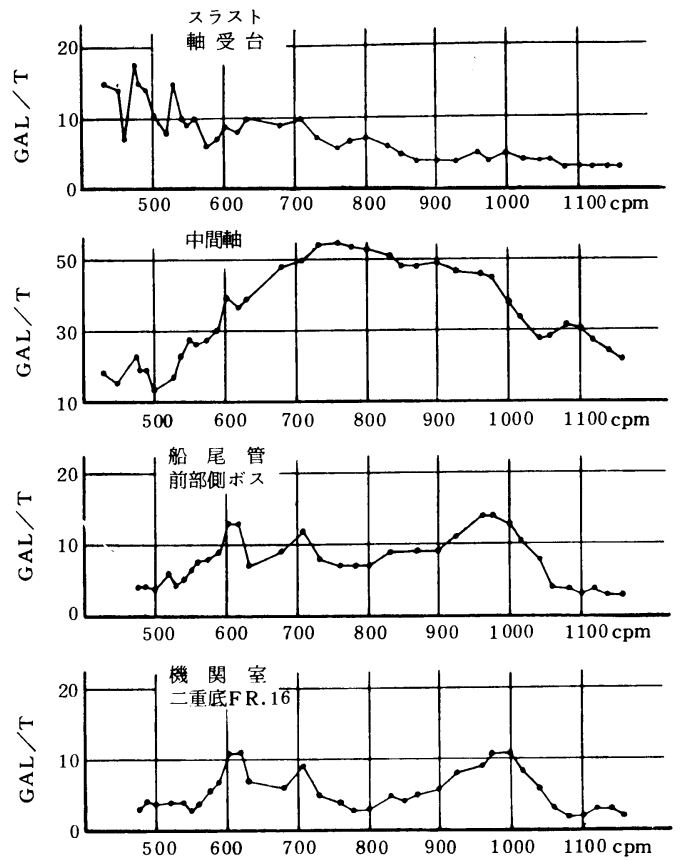

図 2.13 起振テスト結果 ( $\mathrm{C}$ 船)

係留中に中間軸に加振機を取りつけ，加振実験を行なっ た。なお，加振方向は実験装置の都合により水平方向と した。その結果を図 2.13 に示す. $740 \mathrm{cpm}$ 付近に振幅 のピークがあり，この条件における軸系の固有振動数と 考えられる. 計算值との对比については, 次章で説明す る.

\section{3. 軸系横振動計算}

軸系の横振動は, プロペラ起振力によってじゃっ起さ れるが，プロペラ軸と船尾管との間にはすきまがあり， 油膜を介して支持されているので, 軸系の固有振動数の 計算にあたっては，油膜および軸受台支持部の弾性を考 慮する必要がある.さらに，プロペラ軸のふれまわり速 度が軸回転数と異なるので，この影響も考慮して軸系横 振動の計算を行なった.

3.2 計算法について 筆者らは, 以下に述べる 3 種の計算法を用いて解を求め, これらの計算結果が実 船の計測值に合致するか否かを検討した.

（1）多点弾性支持梁で，ふれまわり速度と軸回転数が 異なる影響を考慮した計算. 
表 3.1

\begin{tabular}{|c|c|c|c|}
\hline 項 目 計算方法 & Case (1) & Case (2) & Case (3) \\
\hline 質量が分布している影響 & & & \\
\hline $\begin{array}{l}\text { 慣性モーメント } \\
\left(I_{P}, I_{T}\right)\end{array}$ & & & \\
\hline $\begin{array}{l}\text { ふれまわり速度と軸回転 } \\
\text { 数か潩る影響 }(\omega \neq \Omega)\end{array}$ & & & \\
\hline 軸受部分の質量の影響 & & & \\
\hline $\begin{array}{l}\text { 支持剛性か油膜と軸受支 } \\
\text { 部の弾性とから成り立っ } \\
\text { ている影響 }\end{array}$ & $\underset{\text { 油膜の影響なし }}{X}$ & & \\
\hline $\begin{array}{l}\text { 油膜の堿衰係数とバネの } \\
\text { 連成項の影㮣 }\end{array}$ & & & \\
\hline $\begin{array}{l}\text { 支持剛性が水平と垂直と } \\
\text { で異る影響 }\end{array}$ & & & \\
\hline 計 算 の 内 容 & $\begin{array}{l}\text { 特件方程式か雾 } \\
\text { になる } \\
\text { る. }\end{array}$ & 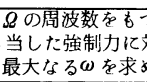 & $\begin{array}{l}\text { 不つり合力に相 } \\
\text { する応答振幅が } \\
\text { る. }\end{array}$ \\
\hline
\end{tabular}

（2）多点弾珄支持，油膜のばね，ふれまわり速度の影 響を考虑した振動計算

（3）多点弾性支持，油膜のばねおよび粘性減衰，軸受 質量, ふれまわり速度の影響を考慮した振動計算。

以上の計算法の計算条件などの比較を容易にするため, 表 3.1 に一覧表を作成したので参照されたい.

Case（1）の詳細説明は省略L, Case (2), Case (3)について詳述する.

\subsubsection{Case (2) 扩よびCase (3) 計算要領}

本計算に当っては, 文献 ${ }^{3)}$ を参考にして, 当社にてす でに作成されていた多点弾性支持における回転軸の振動 に関する電算プログラムをべースとし，これにプロペラ 軸のふれ回り速度が軸の回転数と異なる場合のジャイロ モーメントの影響が考慮されている。このプログラムは 図 3.1 に示すように軸系を多数の円柱に分割し，それぞ れの質量集中点をMassless 軸で結んだものを想定し, 不つり合い質量を適当に与えて，それによって生ずる遠 心力を強制力として働かせ，その応答を算出するように なっている.一方, 軸受部については, 図 3.2 に示すご とく, 軸と軸受間では, 油膜の弾性要素と粘性減衰要素

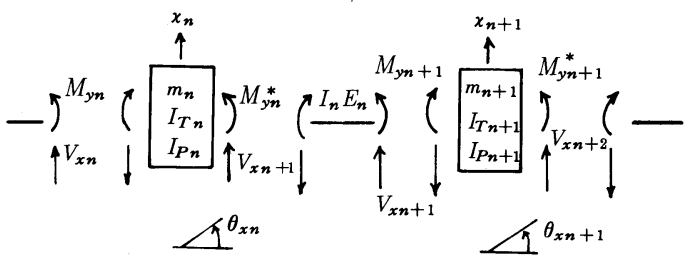

図 3.1 無質量軸の質量集中点

で支持されており，軸受まわり（軸受台の一部を含む） の質量を考慮した．また，軸受と固定点との間では，い ずれも，等方性の減衰要素と弾性要素で支持されている

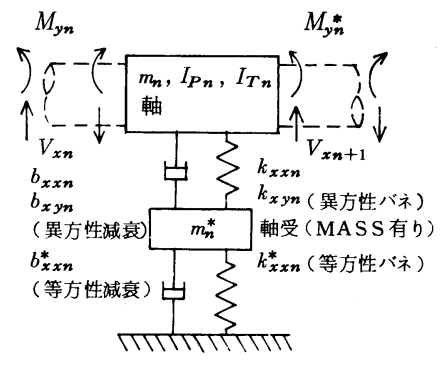

図 3.2 質量付軸受部質量集中点モデル

として計算した.

Case（2）とCase（3）に共通している運動方程方程 式をつぎに示す.

$$
\begin{aligned}
& m_{n} \ddot{x}_{n}= V_{x n}-V_{x n+1}+W_{x n}-k_{x x n}\left(x_{n}-x_{n}^{*}\right) \\
&-k_{x y n}\left(y_{n}-y_{n}^{*}\right)-b_{x x n}\left(\dot{x}_{n}-\dot{x}_{n}^{*}\right) \\
& \quad-b_{x y n}\left(\dot{y}_{n}-\dot{y}_{n}^{*}\right) \\
& I_{T n} \ddot{\theta}_{y n}+\omega I_{P n} \dot{\theta}_{x n}=M_{y n}^{*}-M_{y n} \\
& m_{n}^{*} \ddot{x}_{n}^{*}+k_{x x n}^{*} x_{n}^{*}=k_{x x n}\left(x_{n}-x_{n}^{*}\right)+k_{x y n}\left(y_{n}-y_{n}^{*}\right) \\
& \quad+b_{x x n}\left(\dot{x}_{n}-\dot{x}_{n}^{*}\right)+b_{x y n}\left(\dot{y}_{n}-\dot{y}_{n}^{*}\right)
\end{aligned}
$$

また, $x_{n}=\bar{x}_{n} \cdot e^{\imath \Omega t}, \theta_{y}=\bar{\theta}_{y} \cdot e^{i \Omega t} \ldots \ldots .$. である.

ここで, $x, y$ は変位, $\theta_{y}, \theta_{x}$ はそれぞれ $y$ 軸および $x$ 軸 まわりの傾き角, $V_{x}$ は $x$ 軸方向のせん断力, $M_{y}^{*}, M_{y}$ は $y$ 軸まわりのモーメント, $W_{x}$ は強制力を表わし, $I_{T}, I_{P}$ はそれぞれ，直径まわりの慣性モーメント，極慣性モー メントである。また, $k_{i j}$ は油膜の弾性係数, $b_{i j}$ は油膜 の減衰係数， $\omega$ は回転角速度， $\Omega$ はふれまわりの角速度 を表わす.モーメント以外の*印のついた記号は軸受また はその支持部に関する值を示し, 添字 $n$ は $n$ 番目の值を 表わす. $y$ 方向についての方程式も同じである.

Case (2) とCase (3) の大きな差異は, 図 3.2 およ び図 3.3 に示すごとく, Case (2) は油膜の弾性および 减衰係数, 軸受台のばね定数は, それぞれ, 等方性であ $\eta$, 方程式中の $k_{x y n}, b_{x y n}$ を零とし, 軸受部質量 $m_{n}^{*}$ も 零とおいた。 また, 減衰係数は油膜と支持部を共通とし た。これに対し, Case（3）の場合は，軸と軸受間の油 膜の弾性および減衰係数は異方性を有するものとした。

電算プログラムにインプットされるデータは, 軸の長 さおよび径などの軸形状, 軸受台および油膜の弾性係数,

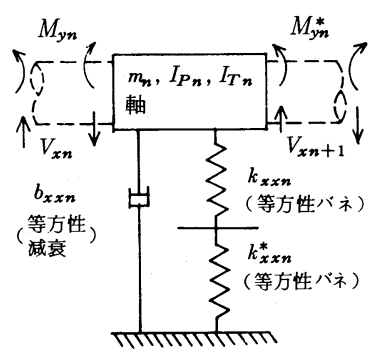

図 3.3 質量無し軸受部質量集中点モデル 
油膜の减衰係数，強制力に相当する不つり合い質量など であり，伝達マトリックス法によって計算されている.

3.2.2 計算に必要な諸俰数そのほかの算出

1) 油膜の弾性係数と減衰係数

本計算にあたって，筆者らは，青木氏，中川氏による “有限幅ジャーナル軸受の油膜俰数の理論解 () ”により 油膜係数を求めた. そこでは, 軸受すきま内の油膜の圧 力分布に関する理論解をもとにして, 油膜の弾性係数お よび減衰係数を求めている.

注）有限幅とあるが, 本計算領域では十分適用可能

2）軸受台のばね定数および付加質量

a）船尾管軸受 (水平方向) ……船尾管まわりの船尾 構造と機関室二重底を, それぞれ, 船尾骨材の上部と二 重底の後部側中間軸受付近で固定された梁とみなして剛 性を計算した。軸受台のばね定数は, 軸受中心に加えら れた荷重に対するたわみ量を計算することにより求める ことが出来る. 船尾管まわりの付加質量として, 船尾管 および船尾管軸受支持構造の一部を含めた.

b）船尾管軸受（上下方向）……機関室二重底に関し ては，a）項で述べた位置を固定点として，曲げモーメン トによる二重底のたわみ量, せん断応力による船尾骨材 のたわみ量, 船尾管のボスの上下方向たわみ量などを合 成し, 総合ばね定数を求めた. また, 船尾管まわりの付 加質量については, 前項と同じ要領で求めた.

c）中間軸受台 (水平方向) ……女ん断応力による二 重底のあらかじめ仮定した固定点に対する軸受中心のた わみ量, および二重底のねじりモーメントによるたわみ 量と，曲げモーメントによるたわみ量を合成してばね定 数を求めた. また, 中間軸受および軸受台の一部を付加 質量として含めた.

d) 中間軸受台 (上下方向)

上記水平方向の場合と同様な方法にて, ばね定数およ び付加質量を求めた。

以上の方法により算定した値を表 3.2 に示す.

3）そのほかの諸㐿数の算出

プロペラ付加慣性モーメン.トおよび付加質量などにつ いては, ロイドの技師により公表されている值 ${ }^{5)}$ を用い， つぎのごとく定めた.

○プロペラ部……直径まわりの慣性モーメントについ の付加慣性てはプロペラの $60 \%$, 極慣性モーメ モーメント ントについてはプロペラの $30 \%$ ，

○プロペラ部……プロペラ重量の $15 \%$

の付加質量

軸受部の支持は幅を無視し，一点に集中していると考 え，支点位置をつぎのようにきめた.

○船尾管後部……軸受メタル後端より $1 / 2 \times$ 軸径 側軸受

。他の軸受……軸受の中央

3.2.3 加振実験に相当する場合の計算 加振実験 に相当する計算条件をつぎのように考えた。実験は軸の

表 3.2 軸受部のばね定数と質量

\begin{tabular}{|c|c|c|c|c|c|c|c|}
\hline & \multirow{2}{*}{ 軸 } & \multirow{2}{*}{ 受 } & \multicolumn{4}{|c|}{ バ衤常数 $\left(10^{6} \mathrm{~kg} / \mathrm{cm}\right)$} & \multirow{2}{*}{$\begin{array}{l}\text { 質 量 } \\
\left(\mathrm{kg} \cdot \mathrm{s}^{2}\right. \\
/ \mathrm{cm})\end{array}$} \\
\hline & & & $k_{x x}$ & $k_{x y}$ & $k_{y x}$ & $k_{y y}$ & \\
\hline \multirow{6}{*}{ B } & BULL GEAR & 油 膜 & 100 & 0 & 0 & 100 & \multirow{2}{*}{0} \\
\hline & 船 & 支持部 & 7.43 & 0 & 0 & 7.43 & \\
\hline & BULL GEAR & 油 膜 & 100 & 0 & 0 & 100 & \multirow{2}{*}{0} \\
\hline & 尾 & 支持部 & 7.43 & 0 & 0 & 7.43 & \\
\hline & \multirow{2}{*}{ 第 1 中間軸受 } & 油 膜 & .814 & -.967 & 1.53 & .545 & \multirow{2}{*}{3.2} \\
\hline & & 支持部 & 3.79 & 0 & 0 & 7.02 & \\
\hline \multirow{4}{*}{ 船 } & \multirow{2}{*}{ 第 2 中間軸受 } & 油 膜 & 1.04 & .156 & 2.11 & 2.25 & \multirow{2}{*}{13.0} \\
\hline & & 支持部 & 1.39 & 0 & 0 & 5.73 & \\
\hline & \multirow{2}{*}{ 船 尾 軸 受 } & 油 膜 & 2.64 & 2.36 & 7.62 & 14.3 & \multirow{2}{*}{85.0} \\
\hline & & 支持部 & .46 & 0 & 0 & 3.95 & \\
\hline \multirow{6}{*}{ C } & BULL GEAR & 油 膜 & 100 & 0 & 0 & 100 & \multirow{2}{*}{0} \\
\hline & 船 & 支持部 & 7.43 & 0 & 0 & 7.43 & \\
\hline & BULL GEAR & 油 膜 & 100 & 0 & 0 & 100 & \multirow[b]{2}{*}{0} \\
\hline & 船 尾 & 支持部 & 7.43 & 0 & 0 & 7.43 & \\
\hline & \multirow{2}{*}{ 中 間 軸 受 } & 油 膜 & 1.23 & -1.68 & 2.48 & 8.01 & \multirow{2}{*}{11.0} \\
\hline & & 支持部 & 3.97 & 0 & 0 & 8.88 & \\
\hline \multirow[t]{4}{*}{ 船 } & \multirow{2}{*}{ 船尾軸船首側 } & 油 膜 & .765 & -.0857 & 1.41 & 1.19 & \multirow{2}{*}{29.0} \\
\hline & & 支持部 & 1.45 & 0 & 0 & 6.55 & \\
\hline & \multirow{2}{*}{ 船尾軸船尾側 } & 伷 膜 & 2.16 & 2.59 & 7.21 & 16.1 & \multirow{2}{*}{88.0} \\
\hline & & 支持部 & 0.95 & 0 & 0 & 5.72 & \\
\hline
\end{tabular}

生：(1) BULL GEAR 軸受の油膜のバ紊常数は無視する意味で大さい 値老使用

(2) CASE 2 ではすべて $k_{x y}=k_{y x}=0$

静止状態で行なわれるという条件を入れると, 油膜の弾 性および減衰係数は静止状態に対して, 求めなければな らぬが，ここでは簡単のため，軸の低速回転における係 数を用いた. そのほかふれまわり現象がないこと以外は, 回転中の場合と同じである.

\section{3 軸系横振動の計算結果とその考察}

各 Case について計算結果を横軸に $\mathrm{cpm}$ をとり粕軸 に振幅の応答をとってグラフに表わしたのが，図 3.4 よ り図 3.8 で, この振幅はプロペラの位置でとり, 実線は

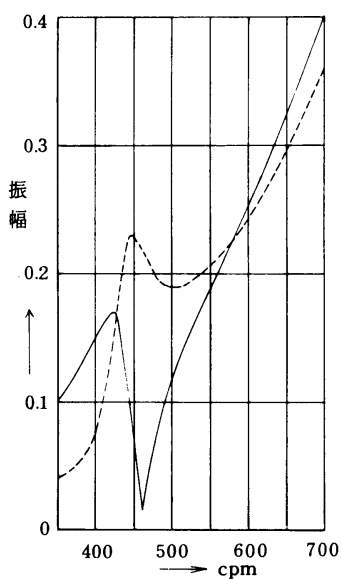

図 3.4 B 船 C A S E 2 航行時

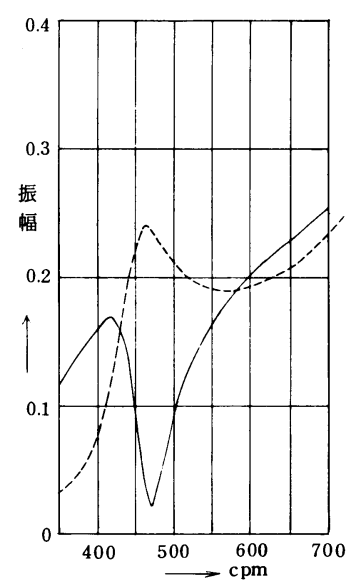

図 3.5 B 船 CASE3 航行時 


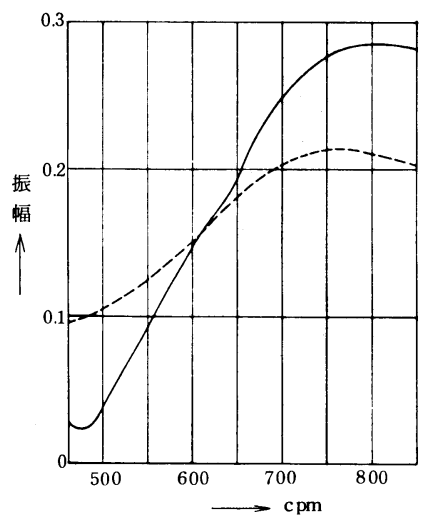

図 3.6 C 船 CASE 2 航行時

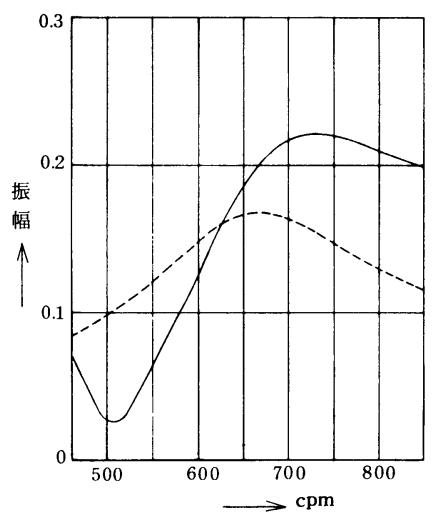

図 3.7 C 船 CASE 3 航行時

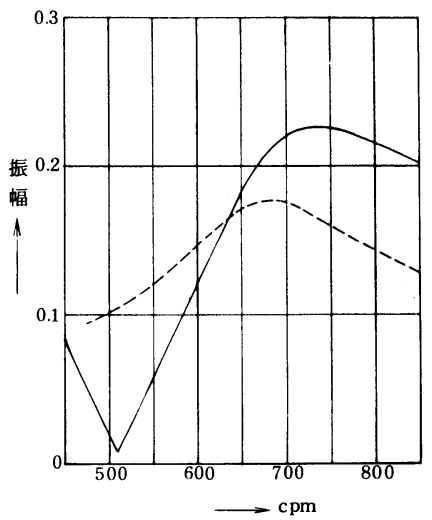

図 3.8 C 船 CASE 3 加振実験時
表 3.3 軸系横振動計算値と実測値

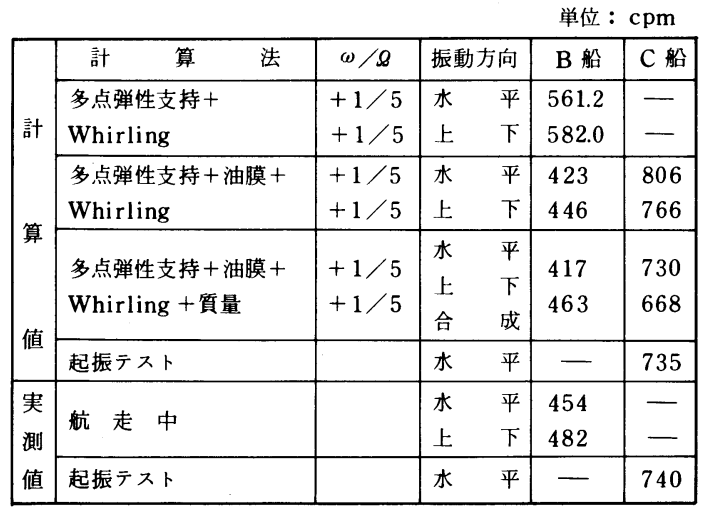

水平振幅, 破線は上下振幅を示した. これらのカーブ上 にて最大振幅の位置をとって固有振動数と見なし，表 3.3 に計算值と実測値をまとめた.

\subsection{1 考 察}

1) B 船の航行時において, Case (1) は計算条件の 不足も影響して可なり実測值と差のあることがわかるが, Case (2), Case (3) とも固有振動数の計算值は実測 值をやや下回っているが，大体近い値となった.すなわ ち, Case (3)に例をとってみると, 水平方向振動の計 算值 $417 \mathrm{cpm}$ に対し, 実測值 $454 \mathrm{cpm}$ 約 $9 \%$ 差であ ク, 上下方向の振動に対しては $4 \%$ 差である.

Case (3) の水平方向と上下方向の固有振動数の差が Case (2)より開いているのは油膜のバネ定数が異方性 であること，油膜の粘性減衰がかなり大きな值であるこ とが原因であると考えられる。

2） C船の航行時において, 固有振動数が水平方向, 上下方向ともCase (2) がCase (3)より 10 ないし 15 \%高くなっており，その傾向がB船と大きく異なってい る.この原因としてあげられる点は，B船には船尾管の 前部側軸受がなく，中間軸受が 2 個あるのに対し， C 船 では船尾管前部側の軸受があり中間軸受が 1 個しかない
ことである。計算結果によりピーク時の振動のモードを 観察すると, C 船では船尾管前部側軸受位置は振動の腹 になっており，この軸受の質量が固有振動数を下げる働 きをしているものと推察される.

3） C 船の加振機実験時に扔いては, 計測結果と実測 值が非常によく合致している.

4）本計算に採用された軸受 mass のとり方，水平方 向，上下方向ばね定数のとり方および最後部軸受の支点 の位置などについて, さらに十分吟味する必要はあるが, 一応，これらの係数そのほかの数值のとり方は，実用性 の範囲にあることを示している.

5) 軸系横振動のモードに関して, 計測結果によると, 計測の範井内ではノードの位置を捉えることが出来なか った。一方，電算のアウトプットではノードの位置が明 示されているので, この矛盾について説明する必要があ る. 理由の一つは, 船尾管内における計測点がないため, 計測上検出出来なかったこと. 2 番目の理由として, 二 重底および船尾管まわりを含む船体のモードとの関係が はっきりしていない点にある.

\section{5.むすび}

3 隻の船について, 主として軸系横振動と船体振動を 測定し, 横振動の共振点に関して計算結果と比較した. この結果, 明らかになったことはつぎのとおりである.

1) A 船，C船においては軸系横振動の振幅が主軸の 回転上昇と共に増加し, 共振点と思われる振幅のピーク は見出されなかったが, B 船の場合には共振点が計測さ れ, この共振点近傍にて船体振動もまた共振している例 が見いだされた.

2） B 船の場合, 共振点に関する計算値と㬰測値が比 較的よく一致した。 また， C船の場合には，加振実験の 結果と計算結果を対比させ, 同様に, よく一致した. 以 上二例の結果より判断して，本計算に用いられた軸受支 持部のばね定数やその他いろいろの係数は, 今後多少修 正・検討の余地はあるが，大体，実用的なものである. 
3）本稿で述べた軸系横振動の計算法を利用して, 今 後つぎの点に留意して軸系計画をする必要がある.

a）横振動の共振点が常用回転数範囲にはいらないよ う，とくに注意しなければならないが，そのためには， 各軸受間のスパンのとり方に十分注意する必要がある. 主として, 最後部軸受の支点位置と尾側より 2 番目の軸 受との間隔は影響度が大である。

b）尾側から二番目の軸受の荷重も，振動モードによ っては重要な要素である.

最後に，筆者らは本稿作成に当り助言いただいた当社 技術研究所の斉藤氏に謝意を表するとともに, 各船デー
タ作成に協力していただいた関係船主殿および呉造船所 第一工場の各位に深く感謝する次第である.

\section{文献}

1) 吉田ほか, 舶用機関学会誌, Vol. 7-8, p. 622

2）藤井克哉：データ集録システムによる船体振動計測と解析, I H I 技報，別冊 4 号, S. 45.10

3) G.W. Lund \& F.K. Orcutt, Trans. A.S.M.E.Series B, Vol. 89, p. 785,1967

4) 中川, 青木 : ジャーナル軸受で支持された回転系の振動, 潤滑, 第 13 巻，第 3 号, 1968, p. 117

5) A.E. Toms, \& D.K. Martyn: "Whirling of Line Shaf ting " Trans, I.M.E. Vol. 84, 1972

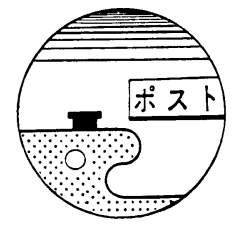

\section{0 年目の曲り角}

世の移り変わりとともに船のェンジンも随分変ってき た. 昔はレシブロェンジンが多く，小形船では焼玉ェン ジンが相当幅をきかせていた，どちらかというと，人が ェンジンを使いこなしていた，現在はどうであろうか， 超自動化船ともなると人が機械に使うれている有様では なかろうか. 機器類のメカニズム, 性能その他を十分知 悉して運航に当らなければならないと思う。

人の集りである団体でも個々の意向を十分洞察して運 営していかないととんでもない方向に進んでしまうこと になる. 本学会も 10 年目を迎え会誌 7 月号には藤田新 会長の挨拶が掲載されており，全会員の支援協力をお願 いしたいと結んでいる.

私は，7月 8 日付で, 学会発展の一助に使ってほしい と手紙を添えわずかな金額を会長あて贈呈した. ところ が，7月16日，会長と面会したおり「今は寄付の公募を していないし，また，副会長や会務委員長とも相談の結 果，お気持は十分いただいておくがお金はお返ししたい」 と多少のやりとりはあったが金額は結局返却された形と なった. また。初めて伺った話であるがこういう発言も あった.「Yさんは役員をおやめになったのでそれを機
会にご寄付をなさった，それは有難く頂だいしました」 と.

私の理解が間違っているのであろうか. それは，時期 は別として役員であった人の寄付は受理できても, 一般 会員の寄付は受理できないのであろうか.

「最近集めた寄付はもう予定額に達しているので貴殿 の寄付は結構です」というような発言もあったが, 一般 の会員に対して寄付公募の会告があったのであろうか. 公募の会告はなかったと思うが私の見落しか。

私は, 理事, 評議員の経験のない正会員 10 名に前述 の寄付の件を聞いてみたが寄付公募の有無にかかわらず 特別な条件がついてないのならフランクに受理すべきで あろうという意見が多かった。

役員の皆さんは日常多忙な方々ばかりで，そのかたわ ら学会の業務を執行されているはずである. しかし, 学 会の運営に当っては役員といえども会員個々の意向を十 分察知して言動すべきではなかろうか.

正会員数も 5,000 名を聞えたと聞いている. 役員もル ールに従って選出されている訳であり，新人も毎年なん 人かは出てきている．理事会の内容は知り得べくもない が役員の新陳代謝により新風をそそぎ本学会のユニーク な点を明確にして運営してもらいたいものである.

10 年ひと昔というが 学会の一部の面である曲り角に きていると思う者は私ひとりであろうか.

（Y.F. 生） 